International Journal of Educational Studies

ISSN: 2641-533X

Vol. 4, No. 3, pp. 81-94.

2021

DOI: $10.53935 / 2641-533 x . v 4 i 3.160$

(C) 2021 by the authors; licensee Academic Publishing Group

\title{
Building a Scale to Measure the Psychological Effects of the COVID - 19 Coronavirus on Omani University Students
}

\author{
*Khalifa Ahmed Humaid Al Qassabi: Assistant Professor University of Nizwa, Oman. \\ Rabia Al Mur Al Dhuhli: Assistant Professor University of Nizwa, Oman. \\ Aaisha Khalifa Ahmed Al Qassabi: Lecturer University of Nizwa, Oman
}

\begin{abstract}
The world was surprised by the outbreak of the COVID-19 pandemic. The pandemic started in China and rapidly spread in the world. This pandemic impacted different aspects of life such as the economy, health, and social life. The study aimed to build a tool to measure the psychological effects of the corona COVID-19 pandemic on Omani university students. The sample of the scale consisted of (566) students from different Omani universities. The researcher used an electronic method to distribute the questionnaire, which was Google Drive. Fifty-nine factors were used in its initial form to measure the psychological effects of the pandemic on Omani university students. The results showed that the tool is an appropriate indication of validity and reality. They revealed the results of factor validity and face validity on a scale consisting of (45) items divided into five areas: thinking about the future, pressures resulting from the requirements of the study, restrictions of movement and communication, and concern about the disease. The study recommended that student councilors and people in charge of Omani universities can use this measure to overcome the psychological effects of the pandemic on students and conduct other studies to verify the applicability to other samples.
\end{abstract}

Key words: Corona, COVID-19, Pandemic effects, Validity, Reliability, Scale building.

\section{Introduction}

Since the beginning of the Corona pandemic, started in China and spread speedily through the world. This was accompanied by many materials and moral consequences that included all sectors of human life. In addition, this pandemic caused an increase in psychological pressure on the human dealing with it, each of the sides that concerns him and affects his life (Wang et al., 2020). Al-Adwan (2020) indicated that the effects of the procedures taken to prevent infection with the virus and to limit social communication operations generated the feeling among many that they were restricted inside their home. Which directly reflected on their mental health.

Historically, it was known that the occurrence and spread of diseases and epidemics in a wide range had their social, psychological, and economic impacts. Due to the fast spread of the COVID-19 virus, it was identified as a novel coronavirus in January 2020. It was first reported in Wuhan, China in December 2019, and in March 2020 the World Health Organization has declared COVID-19 a global pandemic.

The virus has caused global repercussions at the level of the economy, health, social, psychological, and educational levels (Huckins et al., 2020). Studies have found that students were among the groups that suffer from a higher degree of psychological anxiety about learning due to the outbreak of the pandemic. These widespread outbreaks are linked to negative mental health consequences (Yan, Cao, Leung, \& Mak, 2020).

Studies

2021

DOI: $10.53935 / 2641-533 x . v 4 i 3.160$

Corresponding Author: Khalifa Ahmed Humaid Al Qassabi

Funding: This study received no specific

financial support.

Received: 2 September 2021

Revised: 5 October 2021

Accepted: 21 October 2021

(C) 2021 by the authors; licensee Academic

Publishing Group 


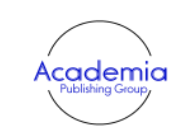

International Journal of Educational Studies

Volume 4, Issue 3, pp. 81-94

2021

DOI: $10.53935 / 2641-533 x . v 4 i 3.160$

"Corresponding Author: Khalifa Ahmed Humaid Al Qassabi

Funding: This study received no specific

financial support.

Article History:

Received: 2 September 2021

Revised: 5 October 2021

Accepted: 21 October 2021

Accepted: 21 October 2021

(C) 2021 by the authors; licensee Academic

Publishing Group
The world has taken various preventive measures, including restricting movement, quarantining at home, closing schools, and other social services. Which led to an increase in psychosocial stress, especially among students (Tadesse, Mihret, Biset, \& Muluneh, 2020).

The first cases appeared in the sultanate of Oman in early March 2020. In the middle of March suddenly all schools and universities were closed and shifted to distance learning. That caused some aspects of confusion for teachers and students in terms of learning and its methods. Moreover, it also raised some questions in terms of unknown conditions and a lack of knowledge of what things would be led to. This was accompanied by decisions that limited social communication, meetings, and direct conversations between students, their teachers, and colleagues. The house is transformed into a new university campus. This came with widespread news about the disease and its description, speculation about its extent, conflicting stories about it, and the transmission of the social, economic, and psychological effects of the epidemic (Wang et al., 2020). With the global development of the COVID-19 pandemic, it was accompanied by widespread psychological problems, anxiety, depression, fears of disease, lack of certainty and clarity about its interactions and consequences (Grubic, Badovinac, \& Johr, 2020).

The pandemic affected many life sectors. One of the important sectors directly affected by this pandemic is the education sector. Education related to location and attendance declined. Students are overwhelmed with challenges and pressures, including university students. Therefore, the educational institutions took quick measures to remedy the responsibilities of education to control the effects of the epidemic. They followed methodologies and methods that were introduced to control the disaster; including social distance and lack of social contact, to slow the spread of this virus (Wilder-smith \& Freedman, 2020).

University students were affected by the procedures taken by countries, which affected their psychological state. Their new learning required using programs and mechanisms for learning, studying, research, and evaluation processes for what they learned. Many of them were not familiar with distance learning through educational platforms, which caused psychological pressure on the students, whether because they dealt with the events, losing their daily way of learning that they were accustomed to, losing their enjoyment of interaction in their universities, and among their colleagues, or fear of the future of their education as a result of some new educational methods that they are unfamiliar with which sometimes seem unstable in some educational institutions that change from time to time.

Higher education students in the sultanate of Oman were affected by the pandemic as were other students in the world. In Oman, students can join one of many universities. On top of those universities: Sultan Qaboos University and the University of Technology and applied sciences which include several technical and applied sciences colleges. In addition, there are several private universities and colleges such as Nizwa University, Al-Sharqiyah university the for university and Suhar university. The ministry of higher education supervises some aspects related to licensing, monitoring, and accreditation of private universities. Students join after completing the 12th grade which is considered the final level of school education to do students. The effect of COVID-19 on Oman's higher education students from not being able to attend in person at a campus, repeated lockdown, and distance learning. All those things affected the psychological health of many students which was observed by researchers when dealing with their students. Many studies showed the same observation such asTadesse et al. (2020), Wang et al. (2020) and Huckins et al. (2020).

Thus, the pandemic affected the mental health and social well-being of university students, with the pressure it puts on them. These pressure factors are directly related to students in terms of education, profession, income, living place, and close communication with people due to social distancing (Zhang \& Ma, 2020).

Intervention to help students in such circumstances requires clear knowledge of their psychological state and the effects caused by this pandemic on them. This requires the existence of scales through that clear information and data can be accessed. Then the collected information and data can be used to diagnose their needs and build counseling and educational programs for them.

\subsection{Requirements to Build the Scales}

The data collection stage is an important stage for every researcher. This process can only be achieved through research tools in which they collect their data, which are measurement tools or data collection tools. Those tools include scales, these scales are considered as a tool of collecting data and obtaining relevant information most validly and reliably; that validity and reliability give confidence to the information collected 


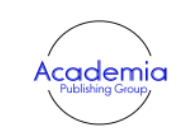

International Journal of Educational Studies

Volume 4, Issue 3, pp. 81-94

2021

DOI: 10.53935/2641-533x.v4i3.160

"Corresponding Author: Khalifa Ahmed Humaid Al Qassabi

Funding: This study received no specific

financial support.

Article History

Received: 2 September 2021

Revised: 5 October 2021

Accepted: 21 October 2021

Accepted: 21 October 2021

(C) 2021 by the authors; licensee Academic

Publishing Group through it. In addition, it provides validity to the results and their interpretation. Validity comes at the forefront of those characteristics, and it is a characteristic that is related to the quality of the scale and the decisions made from the results (Tristán \& Vidal, 2007). In contrast, scales that are lacking validity have many biases, also poorly reliable scales have many random errors associated with their measurement (Coster, 2000). Ackerman (1991) mentioned the existence of an inverse correlation between statement bias and its validity. If the scale has evidence of its validity and reliability, it can be counted with confidence in collecting repeatable data, and that the results are accurate and reliable.

The process of building a scale requires direct entry into the aspects of the problem by the scale preparer to know its various aspects. Which can only be measured through its measurable parts. After collecting those parts that are called the scale's statements, it is necessary to ensure the validity of the formulation and construction. That can only be done through examination of the exact scale prepared with all its parts and statements.

The attention to the statements of the scale comes because they are the observed behavioral parts of the potential characteristic to be measured. Moreover, the strength and validity of the scale come from the strength and validity of its statements, which should be well taken care of when building the scales. Each of the statements carries a part of the characteristic, and it contributes with the other statements in the scale to form the total characteristic or the largest part of what can be measured represented by the whole scale. So, it is necessary to ensure the validity of the statements of each one separately, as the analysis of the statements is an essential step in building psychological scales. Reliability and validity scales can only be obtained through the validity and stability of its statements (Al-Omari, 2011; Anastasi, 1988; El-Sayed \& El-Bahi, 2014).

The researchers reviewed the existing literature about different aspects of COVID-19 effects. Many studies such as Tadesse et al. (2020) and Huckins et al. (2020) came to a result that the most common effects of the pandemic are depression and anxiety. The pandemic also affected the academic performance of students. As per a study that aimed to reveal the impact of the COVID-19 virus on the academic performance of veterinary students by Mahdy (2020), the results showed that the pandemic had affected (96.5\%) of participants with varying degrees.

In China, the epicenter of the first outbreak of the pandemic,Wang et al. (2020) conducted a study aimed at exploring the effects of covid-19 on the mental health of respondents. The results indicate that a sample of health workers showed the repetition of words indicating emotional influences such as anxiety, depression, discontent, and cognitive influences such as social risks and life satisfaction. The results also showed that the respondents are concerned about their health and the health of their families and that their psychological adjustment has decreased. Yan et al. (2020) showed similar results in a study applied on five hundred college students in China during the lockdown period. The results also showed that the negative psychological effects were due to fears of infection, frustration, boredom, insufficient supplies, and insufficient information.

In Ethiopia,Tadesse et al. (2020) conducted a study entitled the psychological effects of COVID-19 among college students in Desi Town, Amhara region. The results concluded that $77.2 \%$ of students suffer from depressive disorder, and 71.8\%; and 48.5\% of students suffer from anxiety and stress disorders respectively. The study revealed that levels of anxiety, stress, and depressive disorders were high, and recommended that local governments should develop effective psychological interventions for students.

Many studies explained anxiety and depression for some identified reasons. In Pakistan, Salman et al. (2020) concluded that the pandemic had a significant effect on students' mental health. The researchers also conclude that anxiety was more in individuals whose family members, acquaintances, or friends were infected. On the other hand, Huckins et al. (2020) found that anxiety and depression increase in the study samples as a result of increasing the pandemic news through the phone and by visiting websites.

\subsection{Concluding Remarks}

After reviewing previous studies by the two researchers, they noticed that most studies deal with the psychological and mental health effects of the COVID-19 virus on students, such as the study of Wang et al. (2020) the study of Salman et al. (2020), Yan et al. (2020) study, and Tadesse et al. (2020). Some of them also studied the academic effects of the COVID-19 coronavirus, such as Mahdy (2020). While the study of examined the effects of the COVID-19 virus on mental health. Also, a study byAl-Hakkak Jaafar's conscience (2012), and Al-Obaidi et al. (2019) focused on extracting validity and reliability and performing factor analysis. 


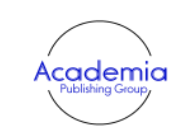

International Journal of Educational Studies

Volume 4, Issue 3, pp. 81-94

2021

DOI: $10.53935 / 2641-533 x . v 4 i 3.160$

"Corresponding Author: Khalifa Ahmed Humaid Al Qassabi

Funding: This study received no specific

financial support.

Article History:

Received: 2 September 2021

Revised: 5 October 2021

Accepted: 21 October 2021

Accepted: 21 October 2021

(C) 2021 by the authors; licensee Academic

Publishing Group
The samples of previous studies were mostly university and college students, except for the study of Wang et al. (2020), their sample was health care and service providers. Thus, it is clear that studies confirm in many regions of the world the effect of the pandemic on university students using the descriptive survey method, and that the questionnaire is the tool of previous studies.

As for the aspects of benefiting from previous studies, the researchers confirm that these studies were the main reference for a lot of information and knowledge that they benefited from in choosing the problem, formulating it, choosing its methodology and procedures, and directing researchers towards many aspects related to the subject.

Therefore, the current study is an extension of those studies in this field and was distinguished from previous studies in its purpose, as it is a psychometric study that aims to build a tool to measure the psychological effects of the Coronavirus pandemic on Omani university students.

\subsection{The Study}

Several studies were conducted to confirm the effect of Coronavirus on the psychological state of university students, the studies of Mahdy (2020), Wang et al. (2020) and Salman et al. (2020). Through the interaction of researchers at the University of Nizwa and communication with colleagues at other universities in the Sultanate of Oman, they felt the need for closest to accurate knowledge about the psychological impact of the pandemic on the students of Oman's universities, which helps in diagnostics, in preparation for the development of therapeutic, indicative and preventive proposals. Where there is no scale available in Oman that measures that effect and the previous studies on the subject did not provide any measures according to the researchers' knowledge, and the old studies provide measures for conditions that may not be suitable with the new pandemic. Hence, the problem of the study is all about the need for a scale of the psychological effect of the Corona pandemic on the students of universities in Oman. This scale has acceptable degrees of validity and reliability indicators.

Previous studies about the psychological effect of the COVID-19 pandemic on higher education students were conducted for students around the world. Oman students are part of the words. So, a specifics study about Oman was needed to acknowledge the social, cultural, and environmental differences.

\subsubsection{Study Questions}

The current study aims to answer the following questions:

1. What are the evidence of the validity of the scale developed to discover the effects of the Coronavirus pandemic on Omani university students?

2. What are the evidence of the reliability of the scale developed to discover the effects of the Coronavirus pandemic on Omani university students?

\subsubsection{Study Aims}

This study aimed to build a scale with psychometric properties: validity and reliability that make it valid for measuring the psychological effects of Corona virus on university students in the Sultanate of Oman.

\subsubsection{Importance of Study}

The scale resulting from this study can add a tool that has acceptable indications of validity and reliability to measure the psychological effects of the Coronavirus. Also, it can help researchers and specialists in their studies and research, and counselors in Oman in diagnosing the psychological state caused by the impact of the Coronavirus on university students in the Sultanate of Oman.

\subsubsection{Study Limits and its Determinations}

The procedures of this study are determined chronologically by the time of the occurrence of the Coronavirus pandemic, objectively by the events of the pandemic and its psychological effects, and by a place targeting university students in the Sultanate of Oman.

\subsection{Terms Definition}

(CORONAVIRUS EFFECTS) on university students: The effect of the spread of the novel coronavirus disease (COVID-19) can be considered, as result of the closure of universities after the World Health 
Organization declared it an epidemic and a pandemic. Because of the growing concern about the pandemic, universities in most parts of the world have postponed or canceled all forms of on-campus teaching, teaching has moved to online platforms, and as a result, a potential impact of the pandemic has emerged on the education and mental health of university students and faculty (Sahu, 2020).

It is procedurally defined by the degree that the respondent obtains on the scale used in this study on university students in Oman.

Validity means that the tool is valid to measure what it was prepared to measure, or in other words when the tool accurately measures any variable described in the study and this tool has been allocated, which is the validity of the measurement tool for what it was designed to measure (Robson, 2011). Chakrabartty (2013) indicated that validity means that there is no bias in the results.

It is defined procedurally in this study as the procedures taken logically and statistically to ascertain the relationship of the data resulting from the scale prepared with the measured characteristic.

Reliability: The extent to which the test scores are free from measurement error, which is that the measurement results are stable, consistent, and free from errors, and indicates that the degree obtained from the measurement is the true amount of the measured characteristic, and the greater the stability, the more accurate the results (Haradhan, 2017).

It is defined procedurally in this research as the procedures taken statistically to ensure the accuracy of the scale prepared in extracting the true amount of what the individual possesses of the measured characteristic.

\section{Method and Procedure}

\subsection{Methodology}

The current study relied on the descriptive approach due to its relevance to the nature of the study objectives. This approach is based on describing the studied phenomenon as it exists in reality and analyzing its components using a field survey (Melhem, 2000).

The community consists of all students in Omani universities, both public and private, who numbered $(52,000)$

\subsection{The Study Sample}

To achieve the purposes of the research, the study sample consisted of (566) male and female students, who answered the scale before analyzing it and after the apparent validity test, which produced 53 items, through Google Drive.

\subsection{The Study Tool}

The initial construction of the effects of Coronavirus pandemic scale on Omani university students was completed after reviewing the theoretical literature through several studies, (Abu-Ghali, Mahmoud Ataf, AbuMustafa, \& Odeh Nazmi, 2016; Ajal, 2015; Bolasal, 2014; Momani \& Naim, 2012), The World Health Organization (2015), and the United Nations (2015). Several statements that measure the intended characteristic were derived, which amounted to (59) statements, then the scale was presented with its 59 statements to 6 arbitrators of experts and specialists from the University of Nizwa and Sultan Qaboos University test the apparent validity. After that, six statements were deleted based on the opinion of the arbitrators and their claim that they are repeated with other statements, so the scale was taken out with 53 statements that were presented to five students to note the extent of its readability, clarity, and their reactions to it, and the wording of some items was modified. Then the scale was applied to the sample consisting of 566 male and female students from universities, and after the application and extracting the psychometric properties of the scale and its statements came out with a scale of (45) statements

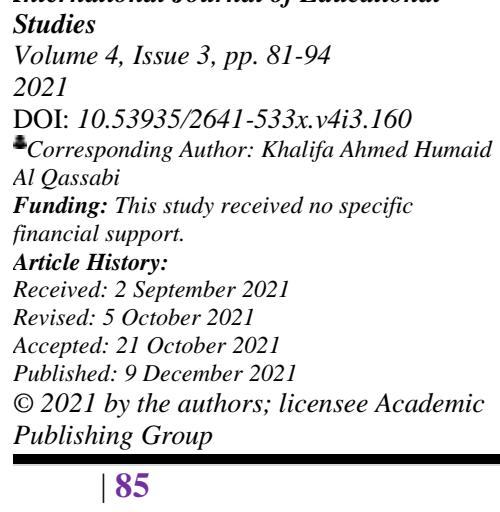

\subsection{Scale Correction Standard}

The alternative answers were given scores $(5=$ very high, $4=$ high, $3=$ don't know, 2 = low, $1=$ very low), so that a high score indicates a high level of effectiveness of the pandemic, a low score indicates a low effect of the pandemic and a score of 3 indicates to the average effect of the pandemic. The scale is also judges on the high, low, or medium degree by examining the averages and standard deviations and finding a $\mathrm{t}$ test for one sample with a hypothetical mean of 3. 


\subsection{Application Procedures}

The scale is built according to the following procedures:

1. Make sure to build the largest possible number of statements, which reached 49 statements.

2. Extracting the apparent validity of the scale and its statements resulted in 53 statements remaining from the scale.

3. An examination of the readability and clarity of the statements for the target audience was presented to 5 students.

4. The data were analyzed after applying the scale to 566 male and female students from Omani universities, and the psychometric characteristics of the scale and statements were extracted. The result was a scale consisting of 45 statements.

\subsection{Statistical Processors}

After the researchers unloaded the collected data, they were processed statistically using the Statistical

Package (SPSS) program, to answer the study questions as follows:

To answer the first question, the following analyzes were carried out:

Exploratory Factor Analysis to find out the factors to which the statements can be classified and their saturation levels.

The corrected correlation coefficient between the statement and the domain to which it belongs after deleting the statement to determine the validity of the statement.

To answer the second question related to the significance of the scale reliability, it was done:

Extracting Cranach's alpha coefficient to calculate the Internal Consistency Coefficient, at the level of the domains resulting from the factor analysis and the level of the scale as a whole.

The statements reliability index was derived by multiplying its correlation coefficient with the domain to which it belongs in its standard deviation.

To answer the first question, which states: What is the evidence of the validity of the developed scale to detect the effects of Corona Virus pandemic on Omani university students?

\section{Study Results and Discussion}

To answer this question, several indications of validity were verified, represented by: apparent validity, factorial validity, statement validity, and peripheral comparison as follows:

\subsection{Virtual Validity}

The validity of the scale was verified by arbitration by presenting it in its initial form of (59) statements to six arbitrators with expertise and competence; To judge the statements of the scale in terms of formulation and belonging to its fields. This resulted in a review of the statements scale, so the wording of a number of them was modified and (6) statements were deleted, so that the scale became (53) statements. To ensure the readability of the statements for the students, it was presented to five students who are available under the pandemic, to review the clarity of the statements for the examinees, and then the wording of some of the statements was reviewed.

\subsection{Factorial Validity}

The factor analysis was performed on the statements of the psychological effects of the corona pandemic scale on Omani university students (53) statements, and the coefficient of determination was (DETERMINANT $=1.841 \mathrm{E}-1)$, which is greater than zero, and the Kaser-Mayer-Olkin KMO coefficient was 0.958 with a statistical significance

$=0.000$, which is greater than 0.5. The matrix of correlations between statements showed that there is a large group of correlations between variables greater than 0.30 , and the one-dimensionality of the scale was examined where it appeared that the first factor alone explains $(20.5 \%)$, which allows performing factor analysis on the scale and its statements to fit the data for the model. The factors were extracted by the Principal Component Analysis method, by using the criterion of latent roots values (EIGENVALUES) for the factor greater than one, and the saturation criterion for the statement with the factor greater than or equal to (0.40). The preliminary analysis resulted in getting nine factors, but it is not meaningful because either there

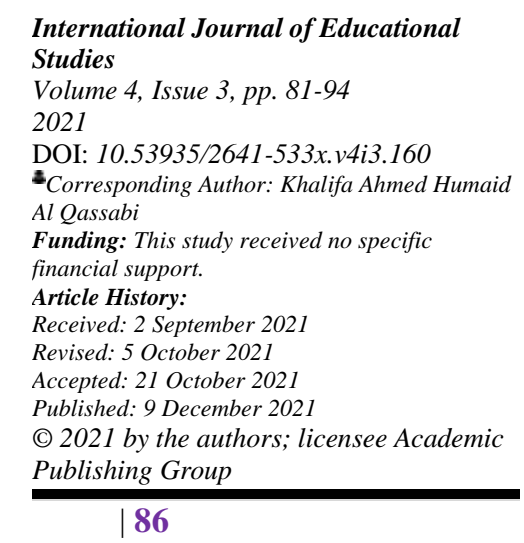


are statements saturated in more than one factor, factors in which one statement is saturated or other statements are not saturated in any factor.

So the factors were rotated orthogonally (ORTHOGONAL) by ARIMA method X), which gave the factorial structure greater clarity that made it possible to review the saturation of the statements with their factors, as it was found that there are still some statements saturated in more than one factor and with simple differences in their saturation, presence of other statements saturated alone in only one factor, and other statements that are not saturated in any factor. So those nine statements were deleted, which are the numbers $(3,4,5,6,17,18,42,43)$, and after deleting those statements, the re-analysis and rotation again resulted in five factors that explained the amount $(61.94 \%)$ of the total variance for the statements. Table 1 shows the rounded factors matrix and the saturation of the statements with the factors.

Table-1. The matrix of rounded factors and the saturation of paragraphs with the factors to measure the effects of the corona pandemic on the students of Omani universities.

\begin{tabular}{|c|c|c|c|c|c|c|}
\hline \multicolumn{2}{|r|}{ Statements } & \multicolumn{2}{|c|}{ Saturates } & \multirow[b]{2}{*}{$\begin{array}{l}\text { Factor } \\
\text { Three }\end{array}$} & \multirow[b]{2}{*}{$\begin{array}{l}\text { Factor } \\
\text { Four }\end{array}$} & \multirow[b]{2}{*}{$\begin{array}{l}\text { Factor } \\
\text { Five }\end{array}$} \\
\hline & & $\begin{array}{l}\text { Factor } \\
\text { one }\end{array}$ & $\begin{array}{l}\text { Factor } \\
\text { Two }\end{array}$ & & & \\
\hline 1 & $\begin{array}{l}\text { I miss the social gatherings we had before } \\
\text { corona virus pandemic }\end{array}$ & & & & 0.68 & \\
\hline 2 & $\begin{array}{l}\text { I miss student gatherings in lectures and other } \\
\text { university situations }\end{array}$ & & & & 0.75 & \\
\hline 3 & $\begin{array}{l}\text { I feel upset from the restriction of my freedom } \\
\text { of movement to move } \\
\text { between different places }\end{array}$ & & & 0.75 & & \\
\hline 4 & $\begin{array}{l}\text { I feel upset from the difficulty of visiting health } \\
\text { centers }\end{array}$ & & & 0.71 & & \\
\hline 5 & $\begin{array}{l}\text { I feel upset from the difficulty of shopping in } \\
\text { malls and shops }\end{array}$ & & & 0.78 & & \\
\hline 6 & $\begin{array}{l}\text { My quality of life has been affected by the } \\
\text { coronavirus pandemic }\end{array}$ & & & 0.59 & & \\
\hline 7 & $\begin{array}{l}\text { I'm worried about the news of the coronavirus } \\
\text { pandemic }\end{array}$ & & & & & 421 \\
\hline 8 & $\begin{array}{l}\text { I feel upset from the cancellation of social } \\
\text { events due to the coronavirus } \\
\text { pandemic }\end{array}$ & & & 0.70 & & \\
\hline 9 & I'm afraid of being quarantined & & & & & 546 \\
\hline 10 & $\begin{array}{l}\text { I'm upset from the impact of the virus on social } \\
\text { distance }\end{array}$ & & & & 0.56 & \\
\hline 11 & $\begin{array}{l}\text { I feel upset from changing the way I lived } \\
\text { before the Corona pandemic }\end{array}$ & & & & 0.65 & \\
\hline 12 & I am afraid of getting the virus & & & & & 626 \\
\hline 13 & $\begin{array}{l}\text { I feel upset of being very careful when meeting } \\
\text { others } \\
\text { I am worried about my academic }\end{array}$ & & & 0.63 & & \\
\hline 14 & future as a result of the coronavirus pandemic & & & & & 0.71 \\
\hline 15 & $\begin{array}{l}\text { I doubt from be able to graduate on time } \\
\text { I feel upset from the lack of clarity about when I }\end{array}$ & & & & & 0.71 \\
\hline 16 & $\begin{array}{l}\text { will return to } \\
\text { university }\end{array}$ & 0.64 & & & & \\
\hline 17 & $\begin{array}{l}\text { I feel insecure about the procedures for the } \\
\text { future of my education }\end{array}$ & 0.76 & & & & \\
\hline 18 & $\begin{array}{l}\text { I suffer from psychological pressure because of } \\
\text { thinking about the future } \\
\text { of my education }\end{array}$ & 0.78 & & & & \\
\hline
\end{tabular}

International Journal of Educational Studies

Volume 4, Issue 3, pp. 81-94

202

DOI: $10.53935 / 2641-533 x . v 4 i 3.160$

Corresponding Author: Khalifa Ahmed Humaid Al Qassabi

Funding: This study received no specific

financial support.

Article History:

Received: 2 September 202

Revised: 5 October 2021

Accepted: 21 October 2021

(C) 2021 by the authors; licensee Academic Publishing Group 
My future academic aspirations conflict with the

19 events of the

0.79

Coronavirus Pandemic

My self-confidence is negatively affected by my

20 worried for my

academic future

I can't get enough information to build

21 perceptions about my future education

My fear of school failure increased due to the

22 presence of the Corona

virus pandemic

I spend a lot of time imagining what

23 my education future might turn out to be $\quad 0.73$

24 I feel insecure about my school future $\quad 0.79$

I am afraid that the corona virus

25 pandemic will be prolonged and affect the 0.74 future of my education

I feel that the chances of happiness with

26 studying will diminish in the

future

I am worried that the virus will

27 cause me difficulties in my future education

I am afraid of the repetition of epidemics in the future

I expect a long period of time for existence of

29 the virus, which will

lead to difficulties in my studies

30 I find it hard to keep up with the change in study methods

I feel weak in my ability to complete the studies load due to the social and economic constraints

31 caused by the Corona virus pandemic

32 I upset of the weakness of the internet

33 I find it difficult to study online

I have doubts about the university's ability to

4 solve the academic problems caused by the Corona virus pandemic

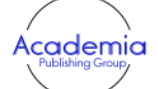

International Journal of Educational Studies

Volume 4, Issue 3, pp. 81-94

2021

DOI: $10.53935 / 2641-533 x . v 4 i 3.160$

Corresponding Author: Khalifa Ahmed Humaid Al Qassabi

Funding: This study received no specific

financial support.

Article History:

Received: 2 September 2021

Revised: 5 October 2021

Accepted: 21 October 2021

(C) 2021 by the authors; licensee Academic Publishing Group
35 I have difficulties on understanding online learning

I'm worried about not understanding all my

36 lessons by online learning

37 I have difficulties on interacting with online lectures

I lost enjoyment and entertainment

38 with the load of following online learning

39 I feel that there is no suitable atmosphere for studying at home

I am missing effective communication with my

40 teachers

due to the coronavirus pandemic 


\begin{tabular}{|c|c|c|c|}
\hline & I miss effective communication & & \\
\hline 41 & with my colleagues because of the virus & & 0.47 \\
\hline 42 & $\begin{array}{l}\text { I miss the feeling of gathering with colleagues } \\
\text { in the classes }\end{array}$ & & 0.69 \\
\hline 43 & $\begin{array}{l}\text { I feel the need for more skills to deal with } \\
\text { distance learning }\end{array}$ & 0.74 & \\
\hline & I find difficulty of subscribe costs & & \\
\hline 44 & $\begin{array}{l}\text { to the Internet to meet the requirements of } \\
\text { distance learning }\end{array}$ & 0.55 & \\
\hline 45 & $\begin{array}{l}\text { I feel confused from the multiplicity } \\
\text { of ways, methods and platforms for distance } \\
\text { learning }\end{array}$ & 0.75 & \\
\hline
\end{tabular}

It is clear from Table 1 that the factor analysis produced factors whose number settled in five factors and statements, which amounted to (45) after deletion. Those factors are: The first factor explained $20.5 \%$ of the variance, it contained (15) statements whose saturation values ranged between (0.79) and (0.56), the statements of this field related to the concern directed towards the academic future, and thus it can be called the field of thinking about the academic future. The second factor explained $18.940 \%$ of the variance and included (14) statements whose saturation values ranged between $(0.81)$ and $(0.55)$., these statements deal with the various problems resulting from the implementation of the requirements of the current education state, hence this field can be called the pressures resulting from the requirements of the study. The third factor explained $11.432 \%$ of the variance, and contained (8) statements whose saturation values ranged between (0.78) and (0.56), its statements related to meetings, visits, and movement in general, it can be called the field of movement and communication restriction. As for the fourth factor, it explained $6.446 \%$ of the variance, and it consisted of (4) statements whose saturation values ranged between (0.75) and (0.47), the statements of this factor related to something of relief through meetings, so this field can be called In social meetings. The fifth factor explained $4.701 \%$ of the variance, and it has (4) statements whose saturation values ranged between (0.63) and (0.42), the statements of this field related to feeling some anxiety about the disease, so this field can be called anxiety about disease.

The component of this scale agrees in the existence and the quality of their psychometric properties with the previous studies conducted on the psychological impact of the COVID-19 pandemic on higher education students. Including the study of Tadesse et al. (2020), Wang et al. (2020) and Huckins et al. (2020). Through which evidence of validity and reliability are presented. This agrees with Al-Hakkak Jaafar's Conscience (2012) that it is important to use factorial analysis because of its importance in experiments. It also provides reliable data and accurate measurements for the scale and its statements (Al-Obaidi et al., 2019).

\subsection{The Statements Validity}

To extract the validity of the statement, the correlation coefficient was calculated between the degree of each statement and the total degree of the dimension to which it belongs after deleting the statement, and Table 2 shows the results of that.

Table-2. Correlation coefficient between the degree of each statement of the tool and the total degree of the dimension to which it belongs.

International Journal of Educational Studies

Volume 4, Issue 3, pp. 81-94

DOI: $10.53935 / 2641-533 x . v 4 i 3.160$

Corresponding Author: Khalifa Ahmed Humaid Al Qassabi

Funding: This study received no specific

financial support.

Article History:

Received: 2 September 2021

Revised: 5 October 2021

Accepted: 21 October 2021

Published: 9 December 2021

(C) 2021 by the authors; licensee Academic

Publishing Group

\begin{tabular}{lllll}
$\begin{array}{l}\text { Thinking about the Pressures } \\
\text { education future }\end{array}$ & $\begin{array}{c}\text { resulted Movement } \\
\text { from } \\
\text { requirements }\end{array}$ & and & restrictions \\
\hline
\end{tabular}

Statement Correlation Statement Correlation Statement Correlation Statement Correlation Statement Correlation

number coefficient number coefficient number coefficient number coefficient number coefficient

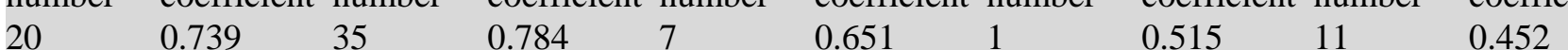

$\begin{array}{llllllllll}21 & 0.684 & 36 & 0.736 & 8 & 0.643 & 2 & 0.560 & 13 & 0.655\end{array}$

$\begin{array}{llllllllll}22 & 0.658 & 37 & 0.568 & 9 & 0.667 & 49 & 0.535 & 16 & 0.643 \\ 23 & 0.796 & 38 & 0.837 & 10 & 0.626 & 50 & 0.699 & 34 & 0.473\end{array}$




\begin{tabular}{llllll}
\hline 25 & 0.795 & 40 & 0.782 & 14 & 0.615 \\
26 & 0.729 & 44 & 0.764 & 15 & 0.685 \\
27 & 0.789 & 45 & 0.776 & 19 & 0.583 \\
28 & 0.736 & 46 & 0.761 & & \\
29 & 0.770 & 47 & 0.681 & & \\
30 & 0.818 & 48 & 0.608 & & \\
31 & 0.802 & 51 & 0.784 & & \\
32 & 0.736 & 52 & 0.736 & & \\
33 & 0.797 & 53 & 0.568 & & \\
34 & 0.695 & 36 & &
\end{tabular}

It is clear from Table 2 that all statements of the scale have correlation coefficients ranged between $(0.45$ - 0.84), so all forty-five items can be trusted in measuring the psychological impact of the Corona pandemic on Omani university students.

\subsection{Peripheral Comparison}

The peripheral comparison represents one of the ways to verify the validity of the scales, and to calculate this validity, the sample scores were arranged in descending order for the scale as a whole, then it was divided into two equal groups, then 150 were selected from the upper category and 150 from the lower category, which represents $27 \%$ of the total sample size in each category, and then the discriminatory ability of the scale was examined using the "T" test for independent samples, as shown in Table 3.

Table-3. T-test to show the differences between the averages of the two extreme groups on the identification of the effects of the Corona pandemic on Omani university students

\begin{tabular}{|c|c|c|c|c|c|c|}
\hline \multicolumn{3}{|c|}{$\begin{array}{l}\text { Low scorers }(n=150) \\
\text { Total scale }\end{array}$} & \multicolumn{4}{|c|}{$\begin{array}{r}\text { High scorers }(n=150) \\
t \text { value }\end{array}$} \\
\hline & 2.452 & 0.295 & 4.277 & 0.456 & $41.17 * *$ & \\
\hline
\end{tabular}

Table 3 shows that there are statistically significant differences at a significance level of less than (0.001) between the average scores of the upper class and the class, and from this it can be said that the scale has a discriminatory ability between students who were affected by the Corona pandemic and those who were low affected. It is clear from the previous analyzes related to validity that the scale with its settled number of statements (45) has many indications of validity represented in the apparent validity, factorial validity, statement validity and terminal differentiation validity, which makes the scale valid and reliable to measure what was prepared for it, which is to collect information on the impact of Corona virus pandemic on Omani university students. To answer the second question, which states: What are the indications of the stability scale developed to detect the effects of the Corona Virus pandemic on Omani university students? To answer this question, Cronbach's alpha coefficient was extracted to calculate the internal consistency coefficient of the scores on each dimension and the total score of the tool, and the stability of the statements was extracted.

\subsection{The Internal Consistency of the Scale and its Domains}

The whole stability of the scale and its five domains were calculated by Krumbach's alpha equation, and International Journal of Educational Studies

Volume 4, Issue 3, pp. 81-94

2021

DOI: $10.53935 / 2641-533 x . v 4 i 3.160$

Corresponding Author: Khalifa Ahmed Humaid Al Qassabi

Funding: This study received no specific

financial support.

Article History:

Received: 2 September 2021

Revised: 5 October 2021

Accepted: 21 October 2021

Accepted: 21 October 2021

(c) 2021 by the authors; licensee Academic

Publishing Group

$$
190
$$

\begin{tabular}{ll} 
Table-4. Values of the stability coefficients by Cronbach's alpha method for degrees on dimensions \\
\hline Dimensions & Stability Coefficients \\
\hline Thinking about the education future & 0.96 \\
Pressures resulted from education & 0.93 \\
requirements & \\
movement and communication restrictions & 0.88 \\
Social meetings & 0.77 \\
Anxiety about disease & 0.76 \\
Total scale & 0.97 \\
\hline
\end{tabular}


Table 4 shows that the values of the stability coefficients for the degree of dimensions ranged between $(0.76-0.96)$, and the stability coefficient for the total degree on the tool was $(0.97)$, and these values are acceptable for the purposes of these studies.

\subsection{Paragraph Stability Coefficient}

The item stability index was calculated by multiplying its validity coefficient by its standard deviation, (Al-Omari, 2011) quoting from ALLEN, YEN, 1986, and Table 5 shows the stability of each statement

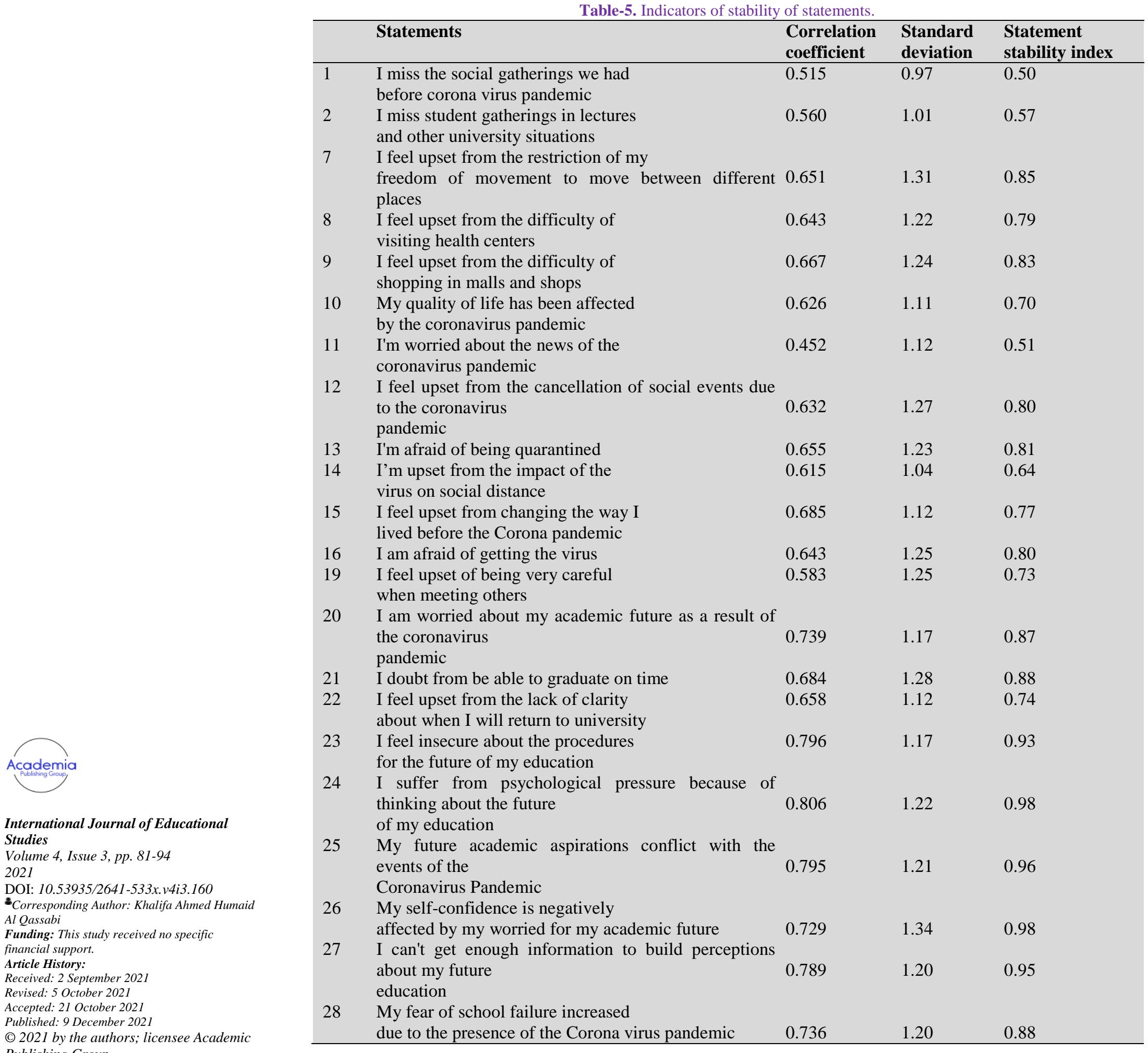




\begin{tabular}{|c|c|c|c|c|}
\hline 29 & $\begin{array}{l}\text { I spend a lot of time imagining what my education } \\
\text { future might turn out to } \\
\text { be }\end{array}$ & 0.770 & 1.20 & 0.92 \\
\hline 30 & I feel insecure about my school future & 0.818 & 1.12 & 0.92 \\
\hline 31 & $\begin{array}{l}\text { I am afraid that the corona virus pandemic will be } \\
\text { prolonged and } \\
\text { affect the future of my education }\end{array}$ & 0.802 & 1.11 & 0.89 \\
\hline 32 & $\begin{array}{l}\text { I feel that the chances of happiness } \\
\text { with studying will diminish in the future }\end{array}$ & 0.736 & 1.20 & 0.88 \\
\hline 33 & $\begin{array}{l}\text { I am worried that the virus will cause me difficulties in } \\
\text { my future } \\
\text { education }\end{array}$ & 0.797 & 1.18 & 0.94 \\
\hline 34 & $\begin{array}{l}\text { I am afraid of the repetition of } \\
\text { epidemics in the future }\end{array}$ & 0.473 & 1.26 & 0.60 \\
\hline 35 & $\begin{array}{l}\text { I expect a long period of time for existence of the } \\
\text { virus, which will } \\
\text { lead to difficulties in my studies }\end{array}$ & 0.695 & 1.18 & 0.82 \\
\hline 36 & $\begin{array}{l}\text { I find it hard to keep up with the } \\
\text { change in study methods }\end{array}$ & 0.784 & 1.19 & 0.93 \\
\hline 37 & $\begin{array}{l}\text { I feel weak in my ability to complete the studies load } \\
\text { due to the social and economic constraints caused by } \\
\text { the Corona virus pandemic }\end{array}$ & 0.736 & 1.19 & 0.88 \\
\hline 38 & I upset of the weakness of the internet & 0.568 & 1.13 & 0.64 \\
\hline 39 & I find it difficult to study online & 0.837 & 1.08 & 0.90 \\
\hline 40 & $\begin{array}{l}\text { I have doubts about the university's ability to solve the } \\
\text { academic problems caused by the Corona virus } \\
\text { pandemic }\end{array}$ & 0.638 & 1.14 & 0.73 \\
\hline 41 & I have difficulties on understanding online learning & 0.782 & 1.22 & 0.95 \\
\hline 44 & $\begin{array}{l}\text { I'm worried about not understanding } \\
\text { all my lessons by online learning }\end{array}$ & 0.764 & 1.21 & 0.92 \\
\hline 45 & $\begin{array}{l}\text { I have difficulties on interacting with } \\
\text { online lectures }\end{array}$ & 0.776 & 1.22 & 0.95 \\
\hline 46 & $\begin{array}{l}\text { I lost enjoyment and entertainment with the load of } \\
\text { following online } \\
\text { learning }\end{array}$ & 0.761 & 1.19 & 0.91 \\
\hline 47 & $\begin{array}{l}\text { I feel that there is no suitable } \\
\text { atmosphere for studying at home }\end{array}$ & 0.681 & 1.29 & 0.88 \\
\hline 48 & $\begin{array}{l}\text { I am missing effective } \\
\text { communication with my teachers due to the } \\
\text { coronavirus pandemic }\end{array}$ & 0.608 & 1.21 & 0.74 \\
\hline 49 & $\begin{array}{l}\text { I miss effective communication with } \\
\text { my colleagues because of the virus }\end{array}$ & 0.535 & 1.25 & 0.67 \\
\hline 50 & $\begin{array}{l}\text { I miss the feeling of gathering with } \\
\text { colleagues in the classes }\end{array}$ & 0.699 & 1.15 & 0.80 \\
\hline 51 & $\begin{array}{l}\text { I feel the need for more skills to deal with distance } \\
\text { learning }\end{array}$ & 0.784 & 1.18 & 0.93 \\
\hline 52 & $\begin{array}{l}\text { I find difficulty of subscribe costs to the Internet to } \\
\text { meet the requirements } \\
\text { of distance learning }\end{array}$ & 0.736 & 1.37 & 0.84 \\
\hline 53 & $\begin{array}{l}\text { I feel confused from the multiplicity } \\
\text { of ways, methods and platforms for distance learning }\end{array}$ & 0.568 & 1.27 & 0.72 \\
\hline
\end{tabular}

Table 5 shows the stability indicators for each of the items on which the scale settled after analyzing the validity, which are (45) items. The stability indicators ranged between $(0.50)$ and $(0.98)$, which are indicators that make the scale valid for measuring the intended characteristic and make its results stable that contribute to know how much the respondents carry from the measured characteristic.

This agrees with what mentioned by Al-Omari (2011) and Busschaert et al. (2015). That it is important to refine the scale statements by dealing with each statement and find its reliability and validity. 


\section{Conclusion and a General Summary of the Results}

Through the previous results, the two questions of the study were answered, and a scale with acceptable psychometric properties was built and applicable within the limits of the society in which it was codified. This scale agrees in its subject and fields with the previous studies, as some of the names of its fields were mentioned in the previous studies,Salman et al. (2020) study, Yan et al. (2020) study and Huckins et al. (2020) study.

\section{Recommendations}

This study aimed to build a tool to measure the psychological effects of the Corona pandemic on students of Omani universities, and from the results of the study, a set of recommendations were reached, the most important:

Benefiting from this scale by student guidance administrators and university administrators in the diagnosis process in terms of identifying the psychological effects of the Corona pandemic on Omani university students, and thus through which appropriate counseling programs can be developed to overcome the problems faced by students that have a psychological effect on them.

Although the scale is a valid psychometric tool that can be adapted for use in studies related to the psychological effects of the COVID-19 pandemic, the researchers suggest conducting other psychometric studies to ensure the scale's applicability to other samples.

\section{References}

Abu-Ghali, Mahmoud Ataf, Abu-Mustafa, \& Odeh Nazmi. (2016). Predicting professional future anxiety in the light of study satisfaction and achievement goals trends among students of psychological counseling in the College of Education at AlAqsa University. Al-Aqsa University Journal, Human Sciences Series, 20(1), 103-141.

Ackerman, T. (1991). A didactic explanation of item bias, item impact, and item validity from a Multi-dimensional Perspective." In Paper presented at the annual meeting of the American Educational Research Association. Chicago: University of Illinois.

Ajal, F. S. (2015). Future anxiety among university youth in the light of some variables. Sebha University Journal Humanities, 14(1), 85-105.

Al-Adwan, D. (2020). The impact of coronavirus pandemic on mental health. Doha Institute for Graduate Studies: Retrieved from: https://www.dohainstitute.edu.qa/EN/News/Pages/Coronavirus-disease-seminar-Psychological-health.aspx.

Al-Hakkak Jaafar's Conscience. (2012). Ideas for proof and proof towards a new vision in psychometrics and educational evaluation, Paragraphs of psychological measurements between logical and appearance analysis for expert and specialized arbitrators and between statistical and factor analysis. Journal of Educational and Psychological Research, Educational and Psychological Research Center, University of Baghdad, 34, 332- 376.

Al-Obaidi, Abdul-Hassan, Abdul-Amir, Al-Qaisi, Omar, F. G., \& Jassem, S. A. (2019). Building a linguistic intelligence scale for primary school students. Journal of the College of Basic Education for Educational and Human Sciences, University of Diyala(45), 237-276.

Al-Omari, H. (2011). The effect of item order in psychological scales on the internal homogeneity of the scale and the characteristics of its items. Damascus University Journal, 27(3+4), 111-129.

Anastasi, A. (1988). Psychological testing (6th ed.). New York: Macmillan.

Bolasal, R. (2014). Future anxiety and its relationship to psychological adjustment among students who are about to graduate, A field study among a sample of third-year undergraduate and second-year master's students. Unpublished Master's Thesis. Larbi Ben M'hidi University - Oum El Bouaghi: Algeria.

Busschaert, C., De Bourdeaudhuij, I., Van Holle, V., Chastin, S. F., Cardon, G., \& De Docker, K. (2015). Reliability and validity of three questionnaires measuring context-specific sedentary behaviour and associated correlates in adolescents, adults and older adults. International Journal of Behavioral Nutrition and Physical Activity, 12(1), 1-13.

Chakrabartty, S. N. (2013). Best split-half and maximum reliability. IOSR Journal of Research \& Method in Education, 3(1), 1-8.

Coster, J. (2000). Scale construction notes. University of Alabama, Department of Psychology.

El-Sayed, \& El-Bahi, F. (2014). Statistical psychology and measurement of the human mind. Cairo: Arab Thought House.

Grubic, N., Badovinac, S., \& Johr. (2020). Student mental health in the midst of the COVID-19 pandemic: A call for further research and mmediate solutions. International Journal of Social Psychiatry.

International Journal of Educational Studies

Volume 4, Issue 3, pp. 81-94

Volum

DOI: $10.53935 / 2641-533 x . v 4 i 3.160$

"Corresponding Author: Khalifa Ahmed Humaid Al Qassabi

Funding: This study received no specific

financial support.

Article History:

Received: 2 September 2021

Revised: 5 October 2021

Accepted: 21 October 2021

Accepted: 21 October 2021

(C) 2021 by the authors; licensee Academic

Publishing Group

Haradhan, K. M. (2017). Two criteria for good measurements in research: Validity and reliability. Annals of Spiru Haret University (Vol. 17). Chittagong, Bangladesh: Premier University.

Huckins, J. F., DaSilva, A. W., Wang, W., Hedlund, E., Rogers, C., Nepal, S. K., . . Meyer, M. L. (2020). Mental health and behavior of college students during the early phases of the COVID-19 pandemic: Longitudinal smartphone and ecological momentary assessment study. Journal of Medical Internet Research, 22(6), e20185.

Mahdy, M. A. (2020). The impact of COVID-19 pandemic on the academic performance of veterinary medical students. Frontiers in Veterinary Science, 7, 732.

Melhem, S. (2000). Find in education and science curricula psychology. Amman: Dar Al-Maysara for Publishing, Distribution and Printing. 
Momani, \& Naim. (2012). Future anxiety among college students in A-Jalil Region in light of some variables. Jordan Journal of Educational Sciences, 9(2), 185-173.

Robson, C. (2011). Real world research, a resource for users of social research methods in applied settings (2nd ed.). John Wiley and Sons Ltd: Sussex, A.

Sahu, P. (2020). Closure of universities due to coronavirus disease 2019 (covid-19). Impact on education and mental health of students and academic staff. Cureus, 12(4), 7541-7759.

Salman, M., Asif, N., Mustafa, Z., Khan, T., Shehzad, N., Hussain, K., . . . Khan, M. (2020). Psychological impact of covid-19 on pakistani university students and how they are coping, aculty of pharmacy. Pakistan: The University of Lahore.

Tadesse, A., Mihret, S., Biset, G., \& Muluneh, A. (2020). Psychological impacts of covid-19 among college students in dessie town. Amhara Region.

Tristán, A., \& Vidal, R. (2007). Linear model to assess the scale's validity of a test. Online Submission.

Wang, C., Pan, R., Wan, X., Tan, Y., Xu, L., Ho, C., \& Ho, R. (2020). Immediate psychological responses and associated factors during the initial stage of the 2019 coronavirus disease (COVID-19) epidemic among the general population in China. International Journal of Environmental Research and Public Health, 17(5), 1729.

Wilder-smith, A., \& Freedman, D. (2020). Isolation, quarantine, and social distancing and community containment: pivotal role for old-style public health measures in the novel coronavirus (2019-nCoV) outbreak. Ethiopia; Cross-statemental Study, 1Samara University. Journal Travel Med, 27(2), 20- 41.

Yan, H., Cao, H., Leung, D., \& Mak, Y. (2020). The psychological impacts of a covid-19 outbreak on college students in china, a longitudinal study. Retrieved from: www.mdpi.com/journal/ijerph. International Journal of Environmental Research and Public Health.

Zhang, Y., \& Ma, Z. F. (2020). Impact of the COVID-19 pandemic on mental health and quality of life among local residents in Liaoning Province, China: A cross-sectional study. International Journal of Environmental Research and Public Health, $17(7), 2381$.

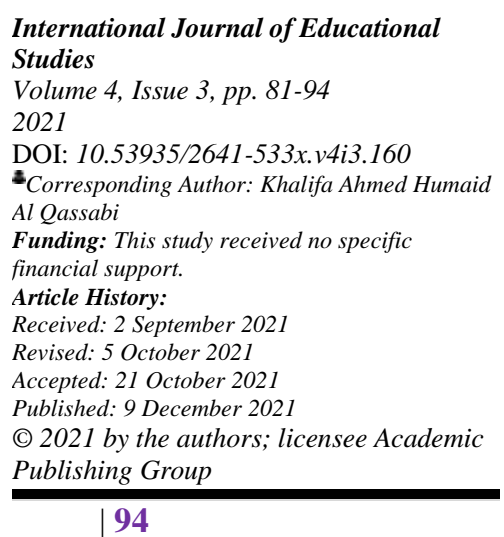

